\title{
COMPARATIVE STUDY OF REGULATORY REQUIREMENTS AND MARKETING AUTHORIZATION FOR MEDICINAL PRODUCTS IN EUROPEAN UNION AND ZIMBABWE
}

\author{
RAJU KAMARAJ, LINDA M BURUWE*
}

Department of Regulatory Affairs, SRM College of Pharmacy, SRM Institute of Science and Technology, Tamil Nadu, India. Email: mklindana@gmail.com

Received: 21 April 2018, Revised and Accepted: 05 June 2018

\begin{abstract}
The aim of this study is to evaluate the requirements for marketing authorization procedures of new drugs, generic medicines in developed countries such as Europe and to compare these procedures with those in developing countries such as Zimbabwe. Medicines control authority of Zimbabwe (MCAZ) grants the marketing authorization for medicinal products in Zimbabwe. However, there are still some gaps which need to be filled by the MCAZ to reach other bigger markets in the world. A comparative study of current MCAZ regulatory administration and practices with those of stringent regulators such as European Union will assist in the identification of these loopholes. It also provides the need for improvement with regard to pharmaceutical industries compliance with the relevant standards. This study will give a tremendous reassurance that the MCAZ regulatory affairs acquiescence is being met and gap analysis will systematically challenge the MCAZ regulatory requirements and procedures by comparing them to the European medicines agency regulatory guidelines, which will provide MCAZ with an insight into areas that have room for improvement. The study provides MCAZ with an insight into areas that have room for improvement. Current GMP Supervision of Manufactures and Inspections need to be upgraded; however, currently in Zimbabwe, there is inadequate internal audits, inadequate quality departments to do the validation and selfinspection in pharmaceutical industries. The comparison results obtained showed grey areas needed to be enhanced by MCAZ.
\end{abstract}

Keywords: Marketing authorization, Medicines control authority of Zimbabwe, European medicines agency, Gap analysis, European medicines agency guidelines.

(C) 2018 The Authors. Published by Innovare Academic Sciences Pvt Ltd. This is an open access article under the CC BY license (http://creativecommons. org/licenses/by/4. 0/) DOI: http://dx.doi.org/10.22159/ajpcr.2018.v11i10.26837

\section{INTRODUCTION}

Zimbabwe is a landlocked country located in the southern part of Africa. It is categorized under the low-to-middle income countries in the world. The national and health-care products in Zimbabwe are regulated by the medicines control authority of Zimbabwe (MCAZ). The MCAZ authority was first established in 1969 as the drug control council. Under the act of parliament, medicines and allied substances act (Chapter 15:03), the MCAZ became a successor of the Drug Control Council and Zimbabwe Regional Medicines Control Laboratory in 1997. The MCAZ reports to the Minister of Health and Child Welfare, but it has a $100 \%$ funding derived from fees collected for services. The MCAZ is responsible for ensuring that all medicines available for sale to the public of Zimbabwe are safe, effective, and of good quality. This authority will ensure that every medicinal product that needs to be marketed in Zimbabwe is registered first before it is distributed to the public. The evaluation and registration division (EVR) is designated to assess the applications for medicinal products [1].

The MCAZ is one of Africa's triumph stories regarding the regulation of medicines and many other health products. In 2012, the MCAZ received a certification from the WHO prequalification program which has led to the expansion and improvement of MCAZ serves in the chemistry laboratory. The quality testing of medicinal products at MCAZ has proved to meet international standards. The MCAZ has supplementary advanced into a service provider for a number of countries in the African region such as Tanzania, Zambia, Ethiopia, Mozambique, and several others [2].

The MCAZ is one of the founding member states of the Southern African Development Committee (SADC) which is known as ZAZIBONA. This is a centralized procedure in which the objective is to provide access to safe, effective, and quality medicines by work sharing in the analysis of applications for registration. This centralized procedure allows inspection of manufacturing testing facilities. The aim is to allow a region which issues good-quality medicines to the public all the time and to significantly decrease the time taken for the approval of marketing authorization in individual countries. They also guarantee efficient utilization of resources within the regional regulatory by sharing their work and evaluations.

However, MCAZ still has a long way to go to meet the world international market of medicinal products. Stringently regulated countries such as the European Union (EU) have set a standard for the marketing and authorization of medicinal products in the world. EU is a giant in the drug regulating markets; it has very stringent requirements for drug development, drug processing, and drug approval. The Medicines Agency (EMA) is a decentralized body of EU which is in charge for the safety and promotion of public health and animal health, through the evaluation and supervision of medicines for human and veterinary use. The EMA was established in 1995 and has worked across EU and globally to facilitate public and animal health assessing medicines to severe scientific standards and by providing partners with independent science-based data. The main objective of the EU pharmaceutical legislation is to safeguard public health while protecting free movement of medicinal products [3].

The EMA is accountable for the assessment of applications for European marketing authorization for medicinal products (centralized procedure). In this centralized procedure, companies must succumb a single marketing authorization application to the EMA which will constantly monitor the safety of medicines through a pharmacovigilance program.

The EMA will take appropriate action if adverse drugs report suggests changes to the benefit-risk balance of a medicinal product [3].

\section{MATERIALS AND METHODS}

Registration requirements in EU

For a medicinal product to be placed on the market in Europe, a marketing authorization has to be issued by the competent authorities 
Table 1: Comparison for EMA and MCAZ

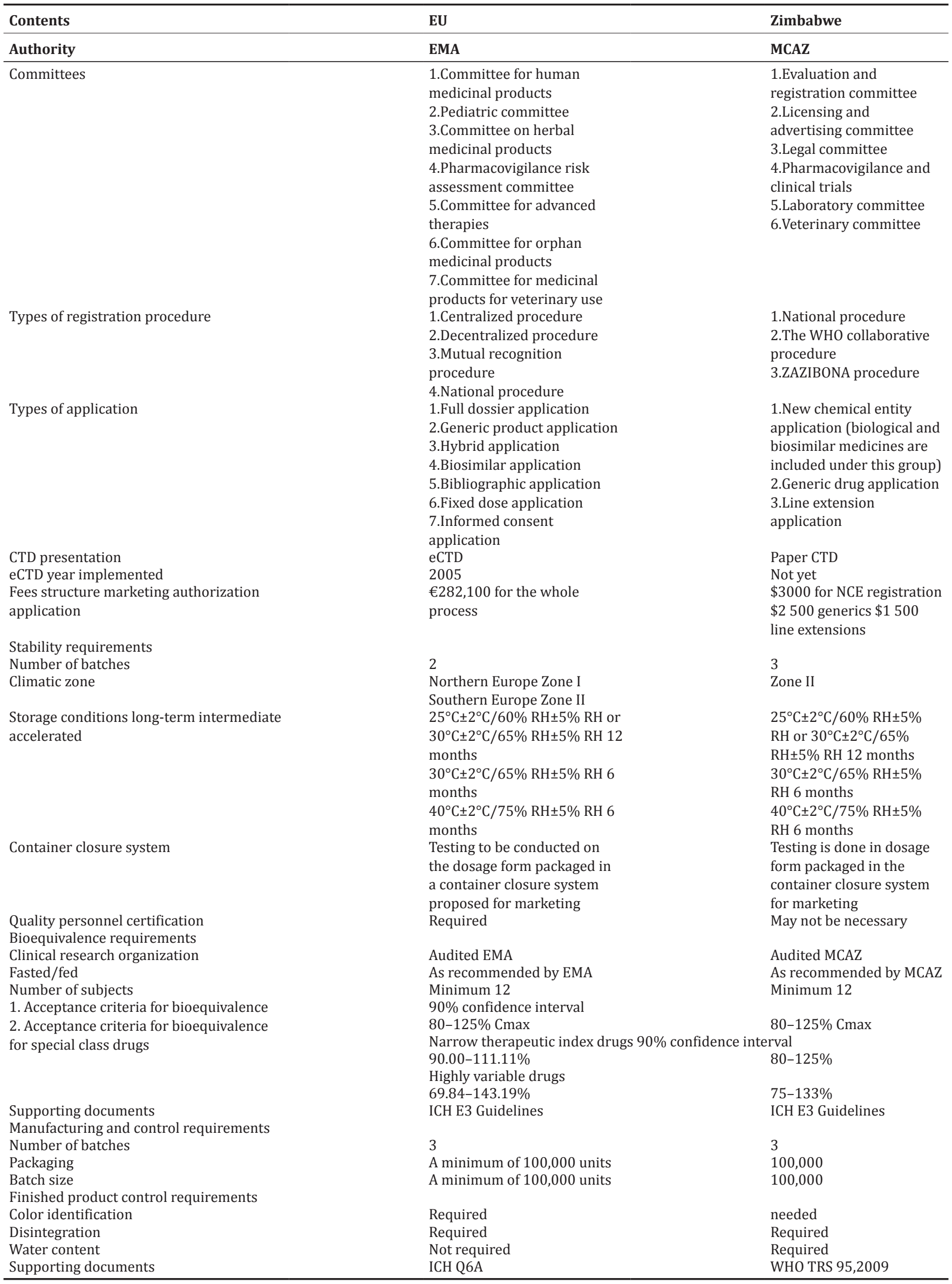

EMA: European medicines agency, MCAZ: Medicines control authority of Zimbabwe 
Table 2: Summary of key national differences

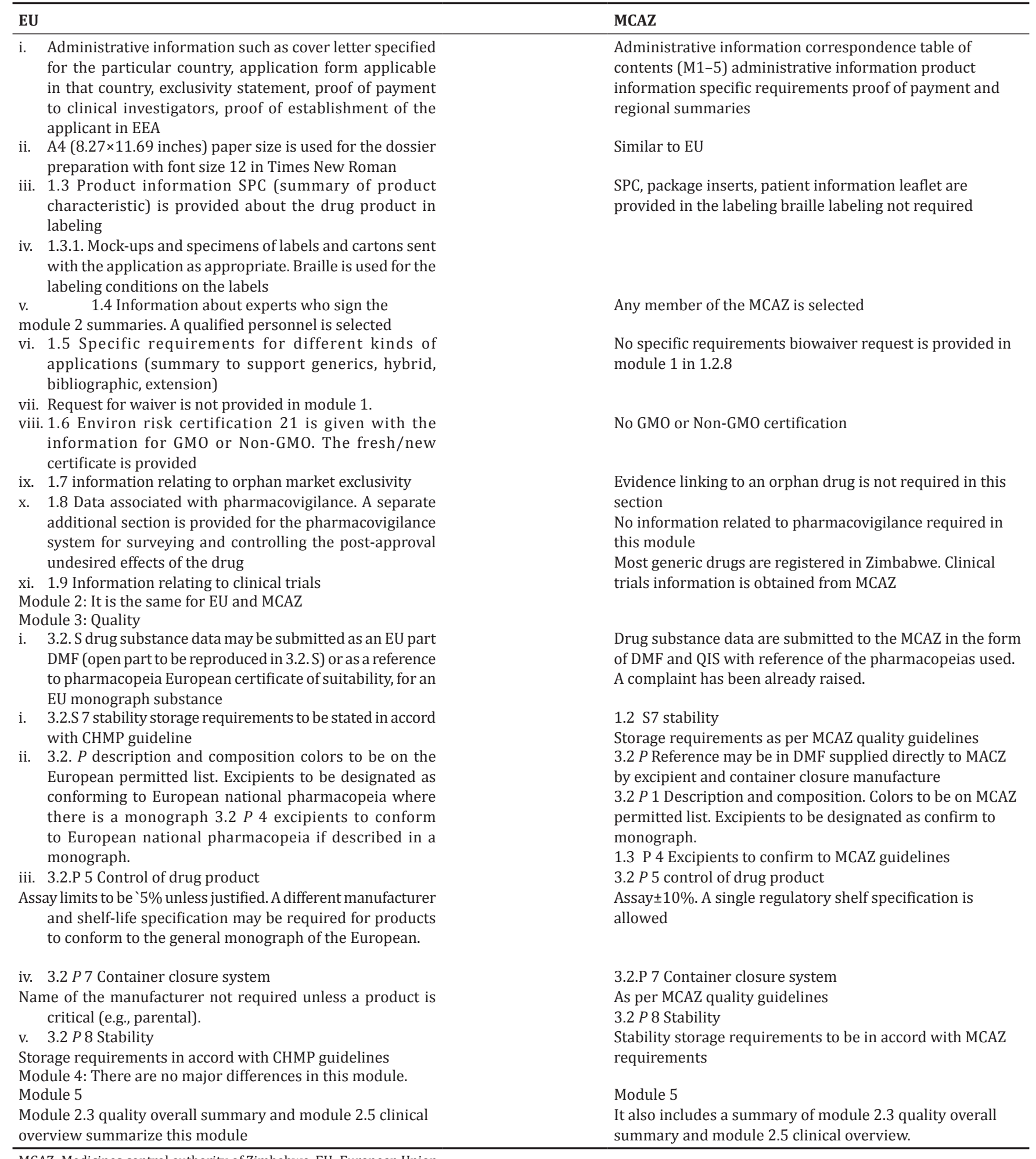

MCAZ: Medicines control authority of Zimbabwe, EU: European Union

of the member state to the applicant. The legal requirements and procedures for making an application for a marketing authorization are outlined in Directive 2001/83/EC and in Regulation (EC) No726/2004. There are four marketing authorization procedures in EU which are the centralized procedure, decentralized procedure, mutual recognition, and national procedure. The centralized procedure is the authorization of medicines, whereby a single application, a single assessment and a single approval throughout the EU. This type of procedure enables the applicant to market the medicinal product and make it available to patients and health-care professionals all over Europe because of a single marketing authorization [4].

Mutual recognition procedure is when the applicant gets marketing authorization in several member states where the medicinal product in question has already received a marketing authorization from one of the member state at the time of application. After the first marketing 
Table 3: Summarized comparison of the Biowaiver requirements for EMA and MCAZ

\begin{tabular}{|c|c|c|c|c|c|}
\hline \multirow{2}{*}{$\begin{array}{l}\text { Criteria } \\
\text { API }\end{array}$} & \multicolumn{2}{|l|}{ EMA } & \multicolumn{3}{|c|}{ MCAZ (WHO BA/BE guidelines) } \\
\hline & BCS Class I & BCS Class III & BCS Class I & BCS Class II & BCS Class III \\
\hline Excipients & $\begin{array}{l}\text { Excipients that } \\
\text { might affect } \\
\text { bioavailability and } \\
\text { qualitatively are } \\
\text { the same }\end{array}$ & $\begin{array}{l}\text { Same excipients } \\
\text { that might affect the } \\
\text { bioavailability and } \\
\text { qualitative }\end{array}$ & \multicolumn{3}{|c|}{$\begin{array}{l}\text { An exhibit that the excipients are well established for use in products } \\
\text { with API and will not lead to any differences with respect to process } \\
\text { affecting the absorption or which may lead to interactions that affect the } \\
\text { pharmacokinetics of API }\end{array}$} \\
\hline $\begin{array}{l}\text { Dissolution } \\
\text { formulation }\end{array}$ & $\begin{array}{l}\text { Very rapid (>85\% } \\
\text { within } 15 \mathrm{~min}) \\
\text { Rapid } \\
\text { dissolution ( } 85 \% \\
\text { within } 30 \mathrm{~min})\end{array}$ & $\begin{array}{l}\text { Very rapid } \\
\text { dissolution }(>85 \% \\
\text { within } 15 \mathrm{~min})\end{array}$ & $\begin{array}{l}\text { Rapid dissolution (NLT } \\
85 \% \text { in } 30 \mathrm{~min} \text { ) }\end{array}$ & $\begin{array}{l}\text { Dose solubility } \\
\text { ratio of }<250 \mathrm{ml} \text { at } \\
\mathrm{pH} 6.8 \text { and rapid } \\
\text { dissolution : (NTL } \\
85 \% \text { in } 30 \mathrm{~min} \text { ) at } \\
\text { pH } 6.8\end{array}$ & $\begin{array}{l}\text { Very rapid } \\
\text { dissolution (>85\% in } \\
\text { within } 15 \mathrm{~min})\end{array}$ \\
\hline $\begin{array}{l}\text { Comparative in vitro } \\
\text { dissolution test }\end{array}$ & \multicolumn{2}{|c|}{$\begin{array}{l}\mathrm{pH} 1-6.8 \text { (at least } \mathrm{pH} 1.2,4.5 \text {, and } 6.8 \text { ) no } \\
\text { surfactant enzymes for gelatin only }\end{array}$} & \multicolumn{3}{|l|}{ pH $1.2,4.5$, and 6.8} \\
\hline $\begin{array}{l}\text { Equivalence } \\
\text { acceptance criteria }\end{array}$ & \multicolumn{2}{|c|}{$\begin{array}{l}\text { Similarity (f2 calculation } 50-100 \text { ) or other } \\
\text { appropriate statistical methods }\end{array}$} & \multicolumn{3}{|c|}{$\begin{array}{l}\text { Similarity (f2 calculation } 50-100 \text { ) or other appropriate statistical } \\
\text { methods, provided that the same criterion is used for acceptance( } \\
\text { maximum } 10 \% \text { differences between the profiles) }\end{array}$} \\
\hline FDC & \multicolumn{2}{|c|}{$\begin{array}{l}\text { FDC products might be acceptable if all API } \\
\text { belong to BCS - Class I or III }\end{array}$} & \multicolumn{3}{|c|}{$\begin{array}{l}\text { FDC product with Class I, II, and III APIs meeting the dissolution criteria } \\
\text { as specified above }\end{array}$} \\
\hline
\end{tabular}

FDC: Fixed dose combination, EMA: European medicines agency, MCAZ: Medicines control authority of Zimbabwe

authorization in the community is granted, the marketing authorization holder may request one or more member state to recognize an authorization granted by the reference member state by submitting an application in accordance with article 28 of Directive 2001/83/EC. The reference member state will provide a list of documents to the concerned member state and applicant which will be validated in 90 days. The documents to be submitted include the assessment report, summary product of characteristics, labeling, and package leaflet. The concerned member state shall assess and approve these documents and inform the reference member state (Kumar, 2015).

The decentralized procedure is whereby an applicant obtains a marketing authorization in several member states where the medicinal product in question has not yet received a marketing authorization in any member state at the time of application. A national procedure is the starting point for mutual recognition and decentralized procedure, this procedure is when an applicant submits an application to an individual competent member state authority of the EU.

\section{Centralized procedure in EU}

Flowchart of centralized procedure show in Fig. 1.

Flowchart: Mutual recognition procedure show in Fig. 2.

Flowchart of decentralized procedure show in Fig. 3.

\section{MCAZ}

To obtain approval to market, sell, and distribute the medicinal product for human or animal use in Zimbabwe, an applicant should register with the Medicine Control Authority of Zimbabwe. The EVR of MCAZ is designated to assess the applications of medicinal products. This division is responsible for reviewing the safety, quality, and efficacy of medicines intended for marketing, sale, and distribution in Zimbabwe. There are three ways of obtaining marketing authorization in Zimbabwe. One is through the national procedure by MCAZ, second is by the WHO Collaborative Procedure, and third is by The ZAZIBONA procedure.

The WHO Collaborative Registration Procedure serves to expedite and fast-track registration of products which have already been assessed and prequalified by the WHO Prequalification team. In the ZAZIBONA process, it is a collaborative registration initiative among four national medicines regulatory authority in Zambia, Zimbabwe, Botswana, and Namibia. The objective of this procedure is to assist in the provision of good quality medicines through work sharing in the assessment of applications for registration and inspection of manufacturing and testing facilities. Medicinal products that pass the evaluation are then provided with an approval for marketing authorization in the participating countries in which applications for registration would have been submitted [5].

Flowchart medicinal product registration by MCAZ Show in Fig. 4.

A schematic overview of the collaborative registration procedure [6].

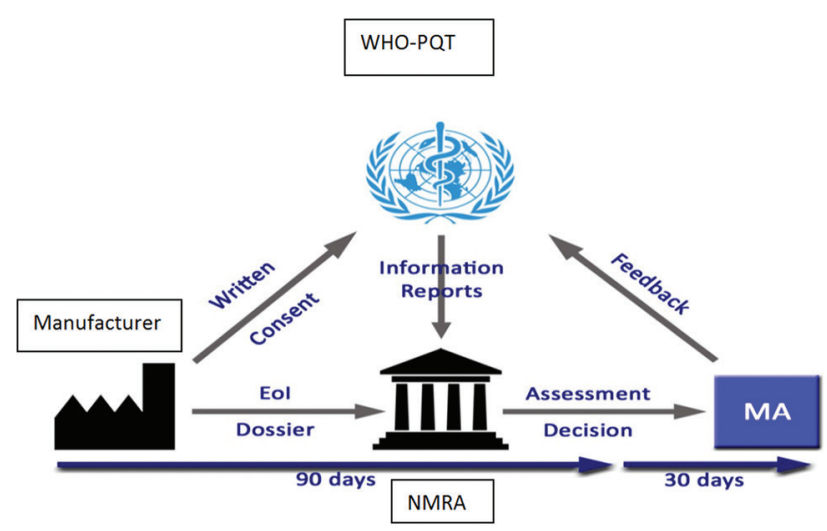

Zazibona process design

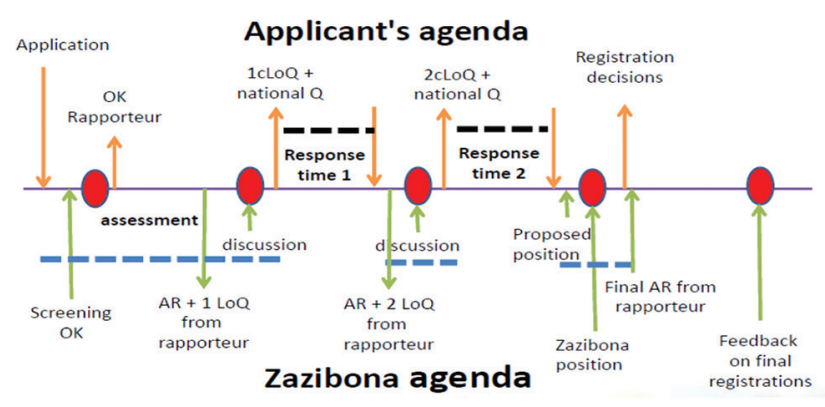


KEY:-

- AR.......................assessment report

- Loq........................... List of questions.

\section{RESULTS AND DISCUSSION}

Comparison of CTD modules.

The Table 4 gives detailed information about procedures and timelines for variations in EU and Zimbabwe [7,8,9 and 10].

This study systematically challenges MCAZ regulatory requirements and procedures by comparing them with the EU standard drug regulations. It helps process improvement in Zimbabwe drug regulatory system [11]. This will enable the MCAZ to determine what actions are necessary for them to be in compliance with the new EU guidelines and requirements. The study provides MCAZ with an insight into areas that have room for improvement $[12,13,14,15]$. Current GMP Supervision of Manufactures and Inspections need to be upgraded. However, currently, in Zimbabwe, there are inadequate internal audits, inadequate quality departments to do the validation and self-inspection in pharmaceutical industries [ 16-40 ]. The MCAZ can resolve this by ensuring that pharmaceutical industries implement frequent inspections determined on risk-based approach as done in EU [41-56].

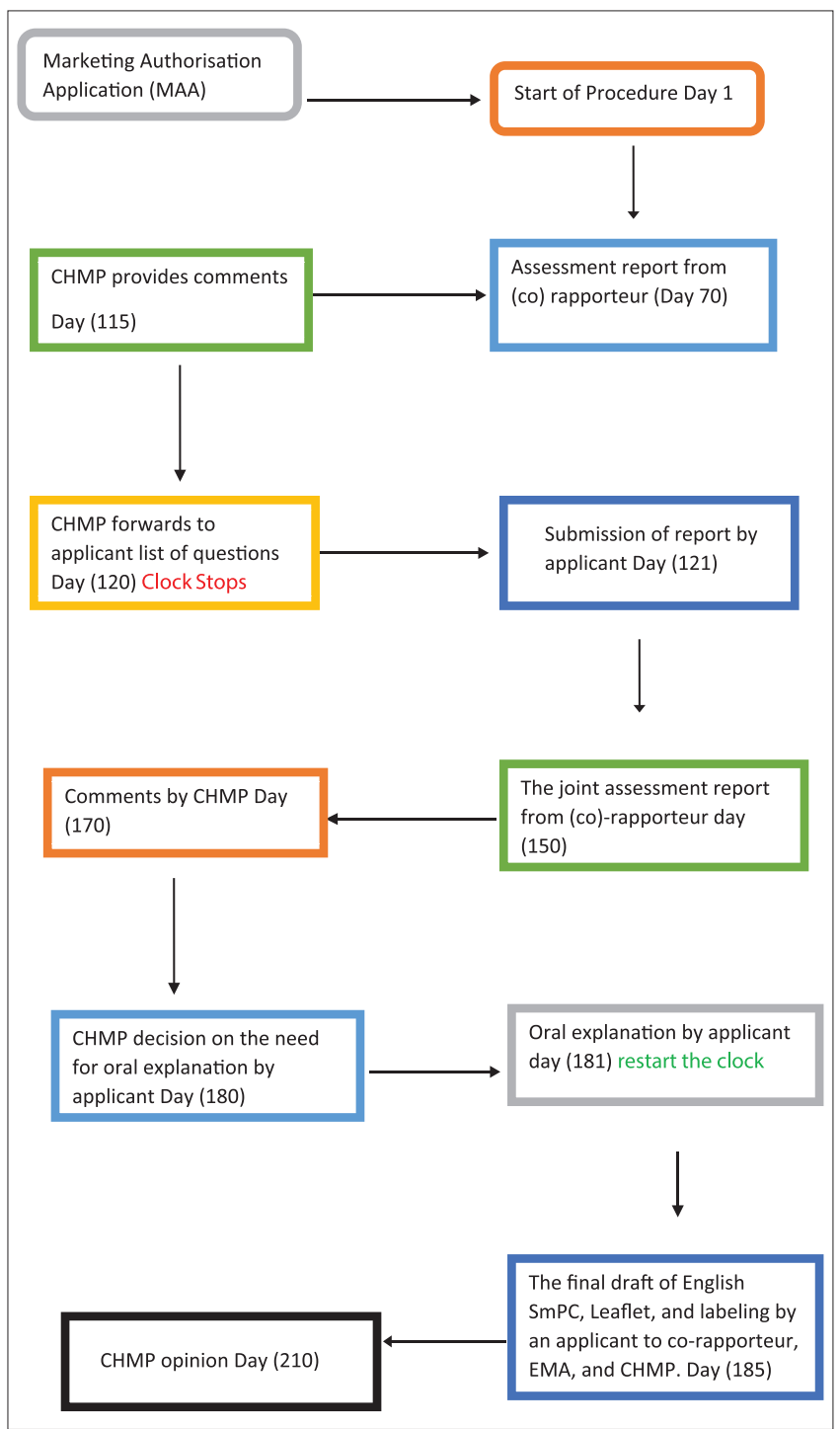

Fig. 1: Centralized procedure

\section{Braille requirement}

In Zimbabwe, the MCAZ lacks in the area of braille labeling on drugs primary package. It can harmonize the braille requirements with that of EMA and address applicants to implement these necessities on the carton of a medicinal product [57-73].

\section{Pharmacovigilance}

A very big gap in this area underreporting of ADR due to common phenomenon of technical and psychological issues.

- Lack of knowledge and understanding regarding the adverse drug reactions reporting system.

- Fear of negative competence among health-care professionals.

- In most hospitals, there is an underestimation of the true size of a problem resulting in ignorance for ADR reporting.

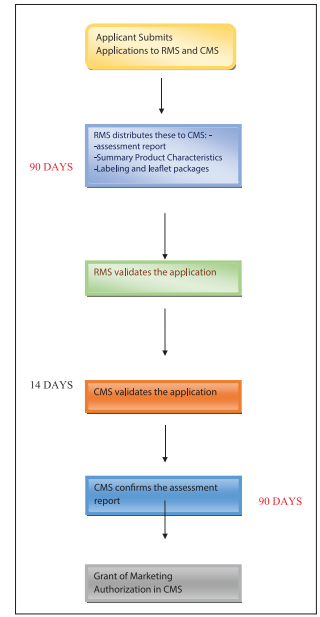

Fig. 2: Mutual recognition procedure

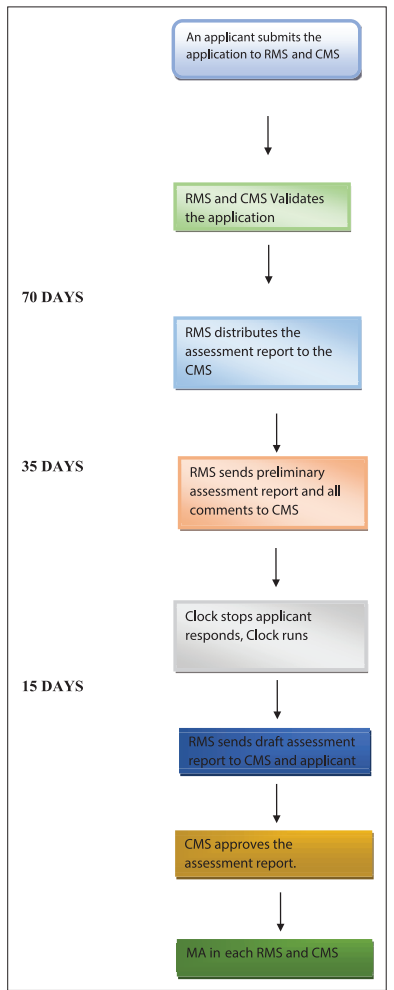

Fig. 3: Decentralized procedure 


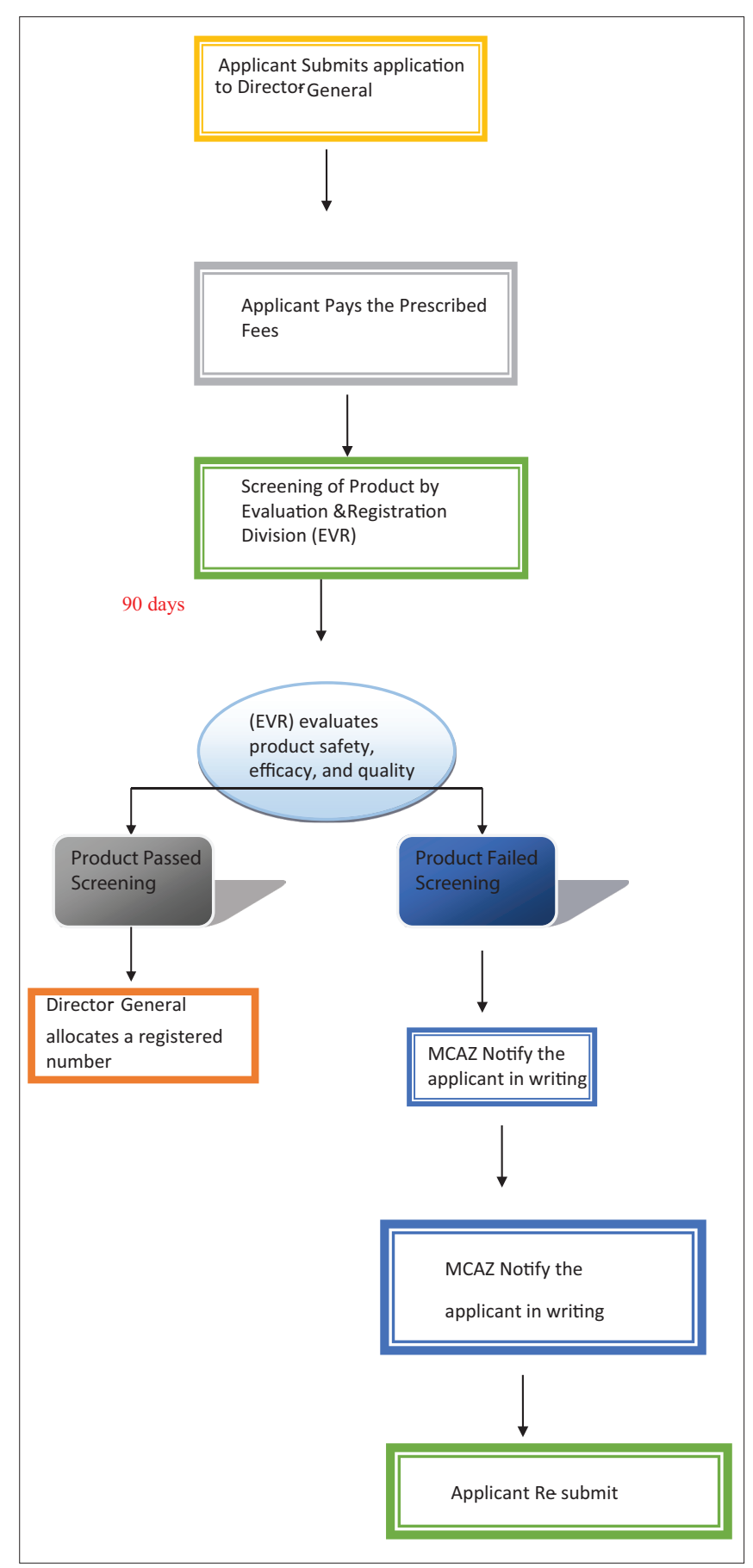

Fig. 4: Medicinal product registration by MCA

Thus, to stimulate the reporting system in Zimbabwe, there should be easy access to reporting forms and other means of reporting. There should be public education regarding adverse drug reaction reporting as this is done in EU, it helps the public to be aware of ADR. (ATUL KHURANA, 2014) MCAZ PVCT team can establish a mobile application in which health-care professionals and consumers can report ADR.

\section{Digitalization}

There is a huge gap in the online application for a marketing authorization in Zimbabwe by the regulatory authority of MCAZ. MCAZ should harmonize their webpage with that of EMA. All important documents should be easily accessed on the website, for example, the GMP guidelines must be available on the website
Table 4: Comparisons of variations in EU and Zimbabwe

\begin{tabular}{|c|c|c|}
\hline \multicolumn{3}{|l|}{ Europe (EMA) } \\
\hline Type of variation & Procedure & Timeline \\
\hline 1.Type IA & $\begin{array}{l}\text { Notification. } \\
\text { "Do\&Tell" and do } \\
\text { not require prior } \\
\text { approval }\end{array}$ & $\begin{array}{l}\text { Notify within } \\
30 \text { days after } \\
\text { implementation. } \\
\text { Notify with } \\
\text { immediate effect, } \\
\text { within } 2 \text { weeks of } \\
\text { implementation }\end{array}$ \\
\hline 2.Type IB & “Tell, Wait and Do" & $\begin{array}{l}\text { Agency will give a } \\
\text { response within } \\
30 \text { days }\end{array}$ \\
\hline 3.Type II & $\begin{array}{l}\text { Require } \\
\text { approval before } \\
\text { implementation and } \\
\text { the variation has } \\
\text { an effect on safety, } \\
\text { efficacy, and quality. }\end{array}$ & $\begin{array}{l}\text { Assessment period } \\
\text { is } 60 \text { days it may } \\
\text { be reduced or } \\
\text { extended up to } \\
90 \text { days, based on } \\
\text { the urgency of the } \\
\text { matter }\end{array}$ \\
\hline 4.Extensions & $\begin{array}{l}\text { These notifications } \\
\text { will be evaluated as } \\
\text { an initial MAA. }\end{array}$ & $\begin{array}{l}\text { It may be } \\
\text { considered } \\
\text { as a new MA. } \\
\text { Assessment may } \\
\text { take 60-90 days. }\end{array}$ \\
\hline \multicolumn{3}{|l|}{ Zimbabwe (MCAZ) } \\
\hline Type of application & Procedure & Timeline \\
\hline 1.Minor variation & $\begin{array}{l}\text { The applicant } \\
\text { submits an } \\
\text { application to MCAZ }\end{array}$ & $\begin{array}{l}\text { Within duration } \\
\text { subject to MCAZ } \\
\text { response }\end{array}$ \\
\hline 2.Major variation. & MCAZ evaluates & $\begin{array}{l}\text { Within duration } \\
\text { subject to MCAZ } \\
\text { response }\end{array}$ \\
\hline
\end{tabular}

EMA: European medicines agency, MCAZ: Medicines control authority of

Zimbabwe, EU: European Union

rather than to let an applicant visit the MCAZ premises to collect the guidelines. The website must be updated on a daily bases. There is a gap in the capacity of assessing and registering new products and to carry clinical trials of new drugs for neglected diseases that are necessary to establish safety and efficacy in Zimbabwe. The SADC has pursued harmonization of registration procedures with a mutual recognition process akin to that of Europe. There is still a gap in the effort put by SADC in relation to focus on NCEs. The SADC should put more effort to harmonize formulation of NCEs rather than on generic products only [ 74-81].

\section{CONCLUSION}

EU with its communal and mutual recognition procedures to enable one dossier to oblige for all is a well-established exemplary for harmonization of drug registration. Thus, the MCAZ and SADC should correspond with EU guidelines to enable improvement of a common scientific framework for assessing medicines and safeguarding the legislation which is enacted to support the assessments. Harmonization of EU and SADC documentation will enable manufacturers to prepare the same dossier for each authority, although there are still country-specific requirements such as the product information documents. Registration of medicines needs to be vigorously embarked on by the MCAZ. Factors responsible for the small number of registered medicines need to be determined so that remedial action can be taken. Subsequently, Zimbabwe is resource constrained, allocation of information, and facilities to register medicines in the subregion must be stimulated. To address the human resources, restraints for MCAZ investment in the training of the human capital for efficient implementation of various functions of regulation should be mandatory. To ensure greater value for harmonization and benefits, the MCAZ and Zazibona member states should build capacity 
for better sharing of resources. To strengthen WHOPQP programs, tolerable funding is required to support operations and regional activities. Consequently, Government should offer an adequate grant to support program implementation by MCAZ; the manufacturing pharmaceuticals should access and use most of the industry fees for production of new drugs.

\section{ACKNOWLEDGMENTS}

The authors would like to thank SRM Institute of technology, SRM College of pharmacy.

\section{AUTHOR'S CONTRIBUTIONS}

My gratitude goes to Ms. Linda Buruwe who has collected the data and drafted the article.

Dr. R. Kamaraj is my guide and has reviewed this article.

\section{CONFLICTS OF INTEREST}

None.

\section{REFERENCES}

1. Medicines Control Authority of Zimbabwe. Available from: http:// www.mcaz.co.zw/. [Last accessed on 2018 Feb 27].

2. European Medicines Agency. Available from: http://www.ema.europa. eu/ema/. [Last accessed on 2018 Feb 28].

3. Medicines and Allied Substances Control General Regulations 1991 SI 150 of 1991.

4. European Medicines Agency Directive/2001/83/EC. Available from: http://www.ema.europa.eu/docs/en GB/document library/ Regulatory_and_procedural_guideline/2009/10/WC5000044̄81.pdf. [Last accessed on 2018 Mar 04].

5. Southern African Development Community: Pharmaceuticals. Available from: http://www.sadc.int/themes/health/pharmaceuticals/. [Last accessed on 2017 Nov 26].

6. Santosh KN. Marketing authorization of human medicinal products to European Union/European economic area. Int J Pharm Sci Rev Res 2011;10:1-8.

7. SADC Pharmaceutical Business Program Available from: https:// www.unido.org/fileadmin/usermedia/services/psd/bep/sadc $\% 20$ pharmaceutical\%20business $\% 2 \quad 0$ plan $\% 20$-approved\%20plan.pdf. [Last accessed on 2017 Nov 22]

8. SADC Member State. Available from: http://www.sadc.int/ memberstates/. [Last accessed on 2017 Nov 21].

9. International Convention on Harmonization. The Value and Benefits of ICH to Drug Regulatory Authorities [Advancing Harmonization for Better Health. Geneva: International Convention on Harmonization; 2010. Available from: http://www.ich.org/fileadmin/Public Web Site/ ABOUT_ICH/Vision/Value_Benefits_for_Regulatory_2010.pdf. [Last updated on cited $2015 \mathrm{Dec}$ 01].

10. Alternative Submission Pathways. Available from: http://www.mcaz. co.zw/index.php/alternative-submission-pathways. [Last accessed on 2017 Nov 28].

11. European Medicines Agency Directive/2001/83/EC. Available from: http://www.ema.europa.eu/docs/en_GB/document_library/Regulatory and procedural guideline/2009/10/WC500004481.pdf. [Last accesse $\overline{\text { d }}$ on 2017 Nov 28].

12. Kramer DB, Xu S, Kesselheim AS. Regulation of medical devices in the United States and European Union. N Engl J Med 2012;366:848-55.

13. Ghalamkarpour A. Marketing authorization procedures in the European Union. Making the Right Choice 2009. Available from: http://www. 1snewscr.sgs.com/1snewscr/1snewscr-december-issue/marketing-a. [Last assessed on 2010 May 11].s

14. European Commission. Medicinal products for human use. Presentation and Format of the Dossier Common Technical Document (CTD) Volume 2B. Notice to Applicants. Brussels: European Commission; 2008.

15. European Commission. Procedures for Marketing Authorization. Centralized Procedure. Vol. 2A. Ch. 4. Brussels: European Commission; 2006.

16. Petrova G. Monitoring of national drug policies--regional comparison between Bulgaria, Romania, Macedonia, Bosnia Herzegovina. Cent Eur J Public Health 2001;9:205-13
17. Martine K. A comparison of drug approval At the FDA and the EMEA/ CPMP. Calif West Law Rev 1996;33:Article ID: 10.

18. European Medicines Agency. Available from: http://www.emea. europa.eu/docs/en GB/document library/Medicine QA/2009/12/ WC500012382.pdf. [Last cited on 2017 Sep 25].

19. Central Drugs Standard Control Organization. Available from: http:// www.cdsco.nic.in/. [Last cited on 2017 Sep 16]

20. Heads of Medicines Agencies. Available from: http:/www.hma.eu/ fileadmin/dateien/Human Medicines/CMD h /procedural guidance/ application_for_MA/MRP/2007_05_MRP_flowchart.pdf. [Last cited on 2017 Nov 17].

21. Heads of Medicines Agencies. Available from: http://www.hma.eu/ uploads/media/dep_flowchart.pdf. [Last cited on 2012 Nov 23].

22. Center for Pharmaceutical Information and Engineering Research. Available from: http://www.cpier.pku.edu.cn/doc/06EU/EU\%20(eng). pdf. [Last cited on 2012 Nov 17]

23. Rick NG. Drugs from Discovery to Approval. $2^{\text {nd }}$ ed. Hoboken, New Jersey: John Wiley \& Sons, Inc.; 2009. p. 201.

24. Rick NG. Drugs from Discovery to Approval. $2^{\text {nd }}$ ed. Hoboken, New Jersey: John Wiley \& Sons, Inc.; 2009. p. 202.

25. Berry IR, Martin RP, editors. The Pharmaceutical Regulatory Process. $2^{\text {nd }}$ ed. New York: Informa Healthcare; 2007. p. 45.

26. Rick NG. Drugs from Discovery to Approval. $2^{\text {nd }}$ ed. Hoboken, New Jersey: John Wiley \& Sons, Inc.; 2009. p. 203-4.

27. Rick NG. Drugs from Discovery to Approval. $2^{\text {nd }}$ ed. Hoboken, New Jersey: John Wiley \& Sons, Inc.; 2009. p. 205-7.

28. Rick NG. Drugs from Discovery to Approval. $2^{\text {nd }}$ ed. Hoboken, New Jersey: John Wiley \& Sons, Inc.; 2009. p. 208-10.

29. Berry IR, Martin RP, editors. The Pharmaceutical Regulatory Process. $2^{\text {nd }}$ ed. New York: Informa Healthcare; 2007. p. 46

30. E6 (CPMP/ICH/135/95) Harmonized Tripartite Guideline; 1997.

31. E8 (CMP/ICH/291/95) General Considerations for Clinical Trials; 2010 .

32. International Ethical Guidelines for Biomedical Research Involving Human Subjects. CIOMS; 2002.

33. Prepared by the Council for International Organizations of Medical Sciences (CIOMS). In: Collaboration with the World Health Organization. Geneva: WHO; 2016.

34. The World Medical Association's Declaration of Helsinki. Revised Declaration of Helsinki. Helsinki: The World Medical Association's Declaration of Helsinki; 2010.

35. Moher D, Schulz KF, Altman DG. The CONSORT statement: Revised recommendations for improving the quality of reports of parallel-group randomized trials. Ann Intern Med 2001;134:657-62.

36. Medicines and Allied Substances Control Act (MASCA) [Chapter 15:03]. Available from: http://www.mcaz.co.zw/.

37. MASCA [Chapter 15:03] Statutory Instrument (SI) 150 of 1991. Available from: http://www.mcaz.co.zw/.

38. MASCA[Chapter 15:03] Statutory Instrument Fee Schedule (SI) 178 of 2008.Available from: http://www.mcaz.co.zw/.

39. Guidance for Industry: Product Recalls, Including Removals and Corrections. Available from: http://www.fda.gov/Safety/Recalls/ IndustryGuidance/ucm 129259.htm.

40. Medicines and Allied Substances Control Regulations. http://www.mcaz. co.zw/medicinesandalliedsubstancescontrolregulationsis150of1991.pdf.

41. Pharmaceutical Products Recall Guidelines, 2014, Traders Licensing and Compliance Division of Drug Office Department of health Hong Kong SAR, China. Available from: https://www.drugoffice.gov.hk/ eps/do/en/doc/guidelines forms/Pharmaceutical Products Recall Guidelines.pdf.

42. Republic of Kenya. Pharmacy and Poisons Board, Guidelines for product recall and product withdrawals. $2^{\text {nd }}$ ed. Kenya: Republic of Kenya; 2006.

43. Guideline on Dossier Requirements for Type IA and IB Notifications July 2003. Available from: http://www.pharmacos.eudra.org/F2/ eudralex/vol-2/C/GdVarTypIAB rev0 200307.pdf.

44. Pharmaceutical Quality Information Form (MC8 FORM). Available from: http:/www.mcaz.co.zw/MC8.pdf.

45. Guideline on Submission of Documentation for Prequalification of Multi-source (Generic) Finished Pharmaceutical Products (FPPs) Used in the Treatment of HIV/AIDS, Malaria, and Tuberculosis; 2006.

46. Available from: http://www.mednet3.who.int/prequal/documents/ Guidelines/GuideGenericSubmitDocFPPs_08_2005_WoAn nexes.pdf.

47. WHO Expert Committee on Specifications for Pharmaceutical Preparations. 34 ${ }^{\text {th }}$ Report, 1996. p. 114-154 (WHO Technical Report Series, No.863) and Good Clinical Practices. Available from: http:// whqlibdoc.who. int/trs/WHO TRS 863 (p99-p194).pdf. 
48. Note for Guidance on Validation of Analytical Procedures: Methodology (CPMP/ICH/281/95). Available from: http://www.emea.eu.int/pdfs/ human/ich/028195en.pdf.

49. Note for Guidance on Validation of Analytical Methods: Definitions and Terminology (CPMP/ICH/381/95).

50. Available from: http://www.emea.eu.int/pdfs/human/ich/038195en.pdf.

51. Note for Guidance on Quality of Biotechnological Products: Viral Safety Evaluation of Biotechnology Products Derived from Cell Lines of Human or Animal Origin (CPMP/ICH/295/95).

52. Available from: http://www.emea.eu.int/pdfs/human/ich/029595en.pdf.

53. Note for Guidance on Quality of Biotechnological Products: Analysis of the Expression Construct in Cell Lines used for Production of r-DNA Derived Protein Products (CPMP/ICH/139/95).

54. Available from: http://www.emea.eu.int/pdfs/human/ich/013995en.pdf.

55. Note for Guidance on Quality of Biotechnological Products: Stability Testing of Biotechnological/Biological Products (CPMP/ICH/138/95).

56. Available from: http://www.emea.eu.int/pdfs/human/ich/013895en.pdf.

57. Note for Guidance on Quality of Biotechnological Products: Derivation and Characterization of Cell Substrates used for Production of Biotechnological/Biological Products (CPMP/ICH/294/95).

58. Note for Guidance on Biotechnological/Biological Products Subject to Variations in their Manufacturing Process (CPMP/ICH/5721/03).

59. Available from: http://www.emea.eu.int/pdfs/human/ich/572103en.pdf.

60. Note For Guidance on Specifications: Test Procedures and Acceptance Criteria for Biotechnological/Biological Products (CPMP/ICH/365/96).

61. Available from: http://www.emea.eu.int/pdfs/human/ich/036596en.pdf.

62. WHO-Guideline on Transmissible Spongiform Encephalopathies in relation to Biological and Pharmaceutical Products; 2003.

63. Available from: http://www.who.int/entity/bloodproducts/publications/ en/WHO_TSE_2003.pdf.

64. Note for Guidance on Minimizing the Risk of Transmitting Animal Spongiform Encephalopathy Agents via Human and Veterinary Medicinal Products (EMEA/410/01rev 2).

65. Available from: http://www.emea.eu.int/pdfs/human/bwp/TSE $\% 20$ NFG\%20410-rev2.pdf.

66. Good Manufacturing Practices for Pharmaceutical Products: Main Principle. Annex 4, WHO Technical Report Series No. 908, 2003. Available from: http://whqlibdoc.who.int/trs/WHO_TRS_908. pdf\#page $=46$.

67. Note or Guidance on Stability Testing of New Drug Substances and
Products (ICH Q1A (R2), CPMP/ICH/2736/99).

68. Available from: http://www.emea.eu.int/pdfs/human/ich/23699en.pdf.

69. World Health Organization. A Practical Handbook on the Pharmacovigilance of Medicines used in the Treatment of Tuberculosis: Enhancing the Safety of the TB Patient. Geneva: World Health Organization; 2012.

70. Verma R, Khanna P, Bairwa M, Rajput M. Adverse events following immunization easily preventable in developing countries. Hum Vaccin 2011;7:989-91

71. Annex 5. Pharmaceutical Preparations Forty-fourth Report. Geneva: World Health Organization; 2010. p. 71-2, 235-64.

72. Edwards IR, Lindquist M. First, catch your signal! Drug Saf 2010;33:25760. Available from: http://www.who-umc.org/graphics/24839.

73. Castor O, Edwards IR. Reflections on attribution and decisions in pharmacovigilance. Drug Saf 2010;33:1-5.

74. Howick J, Glasziou P, Aronson JK. The evolution of EVIDENCE Hierarchies: What can Bradford hills, guidelines for causation "e contribute? J R Soc Med 2009;102:186-949.

75. Coulter DM. The new zealand intensive medicines monitoring programme. Pharmacoepidemiol Drug Saf 1998;7:79-90.

76. Kelly WN, Arellano FM, Barnes J, Bergman U, Edwards RI, Fernandez AM, et al. Guidelines for submitting adverse event reports for publication. Drug Saf 2007;30:367-73.

77. Aronson JK, Hauben M. Anecdotes that Provide Definitive Evidence. BMJ, 2006;333:1267-69.

78. Duclos P, Delo A, Aguado T, Bilous J, Birmingham M, Kieny MP, et al. Immunization safety priority project at the World Health Organization. Semin Pediatr Infect Dis 2003;14:233-9.

79. MCAZ Registration Guidelines. Available from: http://www.mcaz. co.zW/PublishedAugust2012. [Last accessed on 2018 Jan 03].

80. ICH M2 EWG eCTD Specifications ICH M2 EWG Electronic Common Technical Document Specifications. Available from: http://www.ich. org/home.html(PDF).ICH. [Last accessed on 2018 Jan 15].

81. IJPS "Providing Regulatory Submissions in Electronic FormatCertain Human Pharmaceutical Product Applications and Related Submissions Using the eCTD Specifications (PDF). US FDA. Vol. 3. Available from: http:/www.softwarecpr.com/Docs/ CDERCBERelectronicSubmissionsGuidance101805.pdf. [Last accessed on 2018 Jan 16]. 